\title{
HISTORICAL MEMORY AND ORTHODOX FAITH: BYZANCE APRÈS BYZANCE IN SOFIA UNDER OTTOMAN RULE ${ }^{1}$
}

\author{
Ivan Biliarsky \\ Institute of Historical Studies, Bulgarian Academy of Sciences, Sofia, Bulgaria \\ Mariyana Tsibranska-Kostova \\ Institute for Bulgarian Language, Bulgarian Academy of Sciences, Sofia, Bulgaria
}

\begin{abstract}
In our article we propose a case study on the character of the veneration of neomartyrs of Sofia in the $16^{\text {th }}$ century and a review of the related literature. We try to argue that the aims of their veneration were religious and political, and that these aims were attained through the exaltation of the Christian faith and the creation and maintaining of a historical memory. The direction of the intended results, however, is not anti-Ottoman, but anti-Islamic; the veneration urged to consolidate the Orthodox Christian congregation. It is to the people of the Orthodox confession, not to the national (in this period mostly "ethnical") community, that the veneration of the neomartyrs was addressed. The strengthening of the congregation could be achieved excellently through the martyr's bearing witness (having in mind that "martyros" means "witness" in Greek); the martyr adds holiness to the place and sacralizes the space of the city, and finally of the whole political milieu. The witness is not only the creator of sacredness, he is also a keeper of the memory of the past. The martyr is a champion because he / she vanquishes the foes of God through his / her martyrdom. As a champion, he is a reminder of the glorious past; as a victor, he is a Defensor fidei in the present. This is a clear confirmation of God's power under different historical circumstances. These ideas directed at the restoration, but only spiritual, of the Christian Empire through the Body of the Church. This explains the absence of any overt opposition against Ottoman power. Therefore, we find here, in Sofia, a conception of Byzance après Byzance of the same type as we find in Constantinople after the fall of the Empire, when the Ecumenical Church adopted part of the Empire's heritage.
\end{abstract}

Key words: Christian Empire, Orthodox Christian community, veneration of neomartyrs, "martyros", historical memory.

Citation. Biliarsky I., Tsibranska-Kostova M. Historical Memory and Orthodox Faith: Byzance Après Byzance in Sofia Under Ottoman Rule. Vestnik Volgogradskogo gosudarstvennogo universiteta. Seriya 4. Istoriya. Regionovedenie. Mezhdunarodnye otnosheniya [Science Journal of Volgograd State University. History. Area Studies. International Relations], 2021, vol. 26, no. 6, pp. 339-351. DOI: https://doi.org/10.15688/jvolsu4.2021.6.25

УДК 94(5)“04/16”:2

ББК 63.3(5)4-37
Дата поступления статьи: 04.06.2021

Дата принятия статьи: 13.09.2021

\section{ИСТОРИЧЕСКАЯ ПАМЯТЬ И ПРАВОСЛАВНАЯ ВЕРА: BYZANCE APRÈS BYZANCE В СОФИИ ПОД ОТТОМАНСКИМ ПРАВЛЕНИЕМ ${ }^{1}$}

\author{
Иван Билярски \\ Институт исторических исследований, Болгарская академия наук, г. София, Болгария
}

\section{Мирияна Цибранска-Костова}

Институт болгарского языка, Болгарская академия наук, г. София, Болгария

Аннотация. В нашей статье мы предлагаем пример исследования почитания новомучеников Софии в XVI в. и обзор относящейся к этой проблеме литературы. Мы пытаемся обсудить тот факт, что цели их почитания были религиозными и политическими, и эти цели были достигнуты путем экзальтации христианской веры, благодаря возникновению и сохранению исторической памяти. Характер полученных результатов, однако, отнюдь не антиоттоманский, но антиисламский; почитание было призвано консолидировать 
православную христианскую общину. Именно православное вероисповедание, а не национальная общность стало предметом почитания новомучеников. Усиление общины могло быть достижимым исключительно благодаря свидетельству свершения мученичества, ибо оно подразумевало понятие «martyros», означавшее в греческом языке «свидетель». Он не только наделяет святостью место и сакрализирует пространство города и, в конце концов, всей политической среды. Свидетель является не только творцом «освящения», но также хранителем памяти о прошлом. Мученик выступает победителем, потому что он или она благодаря его или ее мученичеству побеждает врагов Господа. В качестве его сторонника мученик служит напоминанием о славном прошлом; как победитель он являет собой Defensor fidei в настоящем. Это ясное подтверждение господнего могущества в различных исторических обстоятельствах. Такие идеи направлены на восстановление, и не только духовное, Христианской империи посредством тела Церкви. Это объясняет отсутствие какой-либо открытой оппозиции оттоманской власти. Поэтому мы находим здесь, в Софии, концепцию Byzance après Byzance («Византия после Византии») того же типа, каковой мы находим в Константинополе после падения Империи, когда Вселенская церковь восприняла часть имперского наследия.

Ключевые слова: Христианская империя, Православная христианская община, почитание новомучеников, «мученик», историческая память.

Цитирование. Билярски И., Цибранска-Костова М. Историческая память и православная вера: Byzance après Byzance в Софии под оттоманским правлением // Вестник Волгоградского государственного университета. Серия 4, История. Регионоведение. Международные отношения. - 2021. - Т. 26, № 6. C. 339-351. - (На англ. яз.) - DOI: https://doi.org/10.15688/jvolsu4.2021.6.25

1. Introduction. The Ottoman conquest of the Balkan Peninsula brought about a considerable change therein the established models of social life, the stratification of society and the conceptions regarding state power. In the Middle Ages, these conceptions were always directly related to the idea of the ruler as God's lieutenant in the visible world. This figure and its power required a special environment, which was usually created through the special status of the capital city as a sacred space. For the Orthodox countries of the Byzantine Commonwealth, this status was a heritage from the tradition of Constantinople, the New Rome. The sacralization of space was usually achieved by the concentration of holiness and grace within the capital city. The way to obtain this holiness and grace was to translate to the city the relics of saints, who thus became celestial protectors and intercessors of the ruler, of his power, and of the whole Empire. This translatio reliquii for the benefit of the whole society was in fact the responsibility of the prince, the country's secular ruler [25]. The Osmanlis having established their power over the Christian Balkan states, it could not be expected that a Muslim ruler would continue this tradition. For sure, the sultans aimed to affirm their power over their Christian subjects, and hence, they sought a kind of legitimation of their rule, and a consolidation of the people, but it was not possible to achieve this through this particular ceremony. Nevertheless, it should be said some translationes reliquiarum did take place in the early Ottoman epoch: those of the "Tărnovian" saints Paraskeva, Philothea and the empress Theophanò from Tărnovo to Vidin and then of the first two mentioned from Vidin to Serbia [22], the translation of the relics of saint John of Rila from the former capital to his monastery in Rila mountain [21]. These examples will not be in the center of our research, yet we should ask ourselves what was the goal and the meaning of these acts. It should be said that the Christian people in the Ottoman Empire needed to preserve and recreate their historical memory and the memory of the sacred power and sacred space of the past Christian rulers. According to E. Boeck, the valorization of the past employs history and saints as a frame for commemoration and sanctification of Bulgarian objects and subjects. Hagiographic and homiletic works contributed to the legitimacy of Christianity and created, for the sacred space, a particular aesthetics that would serve the political, ideological and cultural power [23]. These needs and memories could be supported by various actions. One example of commemoration is directly related to our central topic: the reverence for the neomartyrs of Sofia in the $16^{\text {th }}$ century and the new ways and new meanings of the sacralization of the city's space in the historical memory of Christians under Ottoman domination. This, in our view, is an example of the phenomenon that N. Iorga designated as "Byzance après Byzance" [26]. 


\section{Neomartyrdom in Sofia in the}

$16^{\text {th }}$ century. In the course of the $16^{\text {th }}$ century, Sofia, the chief city of the Beglerbeglik of Roumelia, was the location of a specific historical religious phenomenon: during a period of 40 years (from 1515 to 1555), the martyrial deaths of three young men of Sofia led to the consolidation of the local Orthodox community and to a particular spiritual revival. The martyrs were Saint George the Younger of Sofia, Saint George the Youngest of Sofia and Saint Nicholas the Younger of Sofia. Here we could mention the veneration of Saint George the Old, born in Sofia, according to the unique Greek copy of his Vita, who received the martyr's crown in Adrianople on 26 March 1437 $[9$, p. 405]. The latter hagiographic hero will not be in the focus of our present research.

The three above-mentioned Sofia martyrs, and their veneration, have many common traits, which allow us to unite them under a common tradition: they were young, handsome, pious, successful and well-placed in society, and hence attracted the attention of the local Muslims. Two of them were not from Sofia: Saint George the Younger was from Kratovo and Saint Nicholas the Younger came from Ioannina. This fact made their veneration more universal. The schemas of their martyrdoms are likewise quite similar. They were misled by the Muslims, who wanted to convert them and did so by fraud. The three young men were not fighters against Islam, but merely wanted to preserve their Christian faith. A very special element in the narratives is the presence, in every case, of a spiritual master of the future saint, a guide who not only prepared him for the martyrdom, but also encouraged him during the very act of martyrdom and, usually not long after, wrote a Vita and / or composed a divine service for the saint. The devotee's master was a clergyman of high rank, well respected in the city and in good terms with the Ottoman power. The local authorities themselves are usually presented as figures reminiscent of Pontius Pilatus in the Gospel. We see the judge / governor, probably a kadi, presented as a fair and unprejudiced man who did not aim to destroy the young martyr or the local Christian community, yet conceded to the insistence of the Muslim rabble. The rabble was the real persecutor of the martyr, not the official Ottoman authorities. We should note one other trait common to the three Sofia martyrs that is significant for their veneration: in all cases, the martyr's body was destroyed that it might not become a holy relic and a cult object.

All these facts leave the impression of a systematic approach being taken to the preparation of the martyrdoms and the subsequent veneration, an approach aiming at a precise effect: the creation of a local cult that would strengthen and consolidate the city's Christian community. This could happen only through the memory of the imported or locally created divine grace, a commemoration aimed at sanctifying the city, strengthening the faith and making the city a center of piety and devotion. However, the hallowed space does not lead to a feeling of separateness and insularity with regard to the city or the region; the aim is to achieve a universal holiness. In the Christian conception, the city is not simply a single agglomeration but a symbol of the ecumenical commonwealth of the faithful people, conceived of in the same way as in the Liturgy. The city is seen as a fully universal Christian symbol, as it appears likewise in the Eucharist ritual. Its ecumenical meaning in the Orthodox Church is closely connected to the fact that the Eucharist is sacrament that could be performed only once a day by the same priest in the same church, because it recreates entirely, for the entire Universe, the Sacrifice of the Incarnate Logos through the mystical transformation of His Blood and Flesh in the Eucharistic communion.

The Sofia martyrdoms should be studied in close connection with the Balkan and Anatolian context. Martyrdom was a typical phenomenon in the Balkans under Ottoman rule during the $16^{\text {th }}-18^{\text {th }}$ centuries $[31 ; 30 ; 32 ; 29$, p. $32-36 ; 34]$. Training, inspiring, inciting, and, finally, creating a martyr was a widespread practice in the Ottoman Empire during this period. In Mount Athos, there was a special school for martyrs. This practice met with criticism, disagreement and opposition even within the Orthodox Church and the Christian community $[33 ; 35]$. It is not our aim to judge the centuries-old practice; in any case, its presence testifies to the existence of a deliberate policy aimed at an explicit result. That is way we would propose the working hypothesis that the final result of the $16^{\text {th }}$-century Sofia martyrdoms was focused on the recreation of a unified, cohesive and compact Christian community such as had existed in this locality for centuries under various historical circumstances. 
The neomartyrdoms and the Christian revival in $16^{\text {th }}$-century Sofia led to the creation of five literary works, which formed the core of the cultural phenomenon called the Sofia Literary School. Its extant literary legacy consists in:

a) Two Vitae - the Vita of Saint George the Younger, Martyr, of Sofia, by priest Peyo $[2 ; 1 ; 6]^{2}$, and the Vita of Saint Nicholas the Younger, Martyr of Sofia, written by Matthew the Grammarian, the Great Lampadarius (the person who carried candles in Church processions) of Saint Sophia Church [14; 3];

b) Two Services for the same neomartyrs. While the Service for Saint George the Younger presumably was composed by the same author [1], the author of the Service for Saint Nicholas the Younger Martyr has been proven to be a different hymnographer from Sofia, the monk Andrew [7; 8, pp. 265-278];

c) The fifth work is an anonymous Eulogy for all Sofia martyrs [11, pp. 78-91]. It should be pointed out that each of the works dedicated to Saint Nicholas the Younger Martyr and the Eulogy are preserved in only one copy, as part of a single manuscript dating to 1564 . The manuscript itself is preserved under № 1521 in the collection of the Church Historical and Archive Institute of the Holy Synod of the Bulgarian Orthodox Church in Sofia (onward $C_{H A I^{3}} 1521$ ) [10, pp. 75-77; 16, c. $99 ; 15$, pp. $119-120 ; 3$, pp. 51-52; 18].

Martyrdom entailed subsequent veneration, which in turn required appropriate texts (vita, divine services and eulogies). This was a common practice that did not need to be guided by any special policy. Nevertheless, we must have in mind that all these events took place within a relatively short period of time; they involved the participation of high-ranking representatives of the clergy, who also became authors of the texts. We should note the case of the common Eulogy of Sofia neomartyrs, which testifies to a shared attitude to different venerations and formally unites them in a complex, in which they were presented, perceived, conceptualized and glorified together in the same cultural, historical and religious context.

These observations allow us to state that the cited literary works related to the neomartyrs of Sofia form a united, homogenous and well-focused complex, and were meant to serve for the recently established venerations. It is in this aspect that we can appreciate the importance of the manuscript CHAI 1521. It was discovered in the church of Saint Nicholas the Younger in the neighborhood of Üçbunar (Three Fountains) in Sofia, and subsequently was transferred to the metropolitan cathedral of Saint Nedelya or Saint Kyriaki (Saint Dominica) $[12 ; 17$, pp. 1-3; 10, pp. 77, 191; 15, pp. 119-120; 3, pp. 51-52]. The manuscript was studied and partially published by the Russian scholar Polychrony Agapievich Syrku, who worked on it during his mission in Bulgaria after the Russian-Ottoman war (more precisely, from September 1878 to September 1879). The scholar commissioned and paid the local teacher Manol Lazarov, of Sofia, to copy the texts. Based on this source, P. Syrku published the first description of the manuscript and the most important works it contained. At present, the codex CHAI 1521 has 288 paper folia. It can be divided into three parts. The first part was prepared by the calligrapher priest Lazar of Kratovo. The organizing factor in this part is the date of Saint Nicholas the Younger Martyr's death, namely the $17^{\text {th }}$ of May, 1555 . The text is on ff. 41r-209r. Nicholas, a shoemaker, was born in the Greek town of Ioannina, in Epirus; the narrative about his exploit, supplied with the necessary liturgical texts, was added to the Orthodox calendar in the environment of already existing commemorations for the same day. The second part, written by another copyist, consists only of the common Eulogy for the three Sofia martyrs (ff. 202r-222r). The third part comprises fragments and works of various provenances, but gathered together as being all translations (from $\mathrm{ff} .223 \mathrm{r}$ to the end of the manuscript). They come from the hand of an anonymous third author. The manuscript dates from 1564, which was explicitly indicated in priest Lazar's note, written in cryptogram and placed after the Vita of Saint Nicholas the Younger.

The first question is whether priest Lazar merely used a protograph from Sofia, following it in his manuscript of 1564 , or personally compiled the earlier original works. The short sequence of time between the creation of the texts and the writing of the copy testifies in favor of an existing protograph. The gathering together of three original literary works in a manuscript codex is undoubtedly a synthesis of the combined veneration of the three new martyrs of Sofia, as Ivan Snegarov proposed many years ago [12, p. 17]. It seems obvious that 
the local diocese of Sofia needed liturgical and hagiographic texts for the veneration of the local saints, and manuscripts to serve that purpose. Martyrdom was so essential to the Christian value system that each new example of it was subsumed under the model set by the first early Christian martyrs. The early Christian model of martyrdom had a connotation that made it particularly appropriate for emulation in the struggle against pagans and other infidels.

The second problem refers to the fact that the only known copy of these important texts was prepared in Kratovo (Macedonia). This Macedonian town was strongly linked to the whole story of the $16^{\text {th }}$-century Sofia martyrs. The first of these, Saint George the Younger, came to Sofia from his birth place Kratovo. Here he received the martyr's wreath on February 11, 1515. This fact established a shared neomartyrdom tradition for both towns.

\section{The Ottoman power and the historical} context of neomartyrdom. We have already indicated the ruler-related practice of the translation of relics and its purpose to provide special grace for the capital as a sacred place of power $([25 ; 20]$. Also see the studies, collected in book: [27]). This consecration was expressed in particular artistic forms as well as in panegyric formulae. The capital cities are usually called "God-saved", "God-protected", etc., and the ruler is "faithful", "pious", "Christ-loving". In this respect, we should note the very important figure of knez Dimiter of Kratovo, who is mentioned in the dedication notes of both manuscripts from Sofia and Kratovo, related either to the neomartyrs, or to Matthew the Grammarian, the author of the Vita of Saint Nicholas the Younger. In the 1562 Gospel, the scribe's note states that the manuscript was prepared in м'ъст' $\mathrm{K}_{\text {ратово ("town }}$ of Kratovo") [17, pp. 16-17]. The knez Dimiter himself was mentioned as a real medieval ruler:

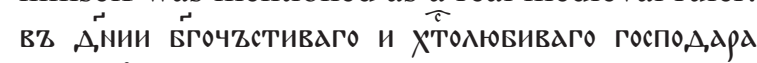
кнеSג Аимитрїа. The cited encomia usually refer to sovereigns, not local figures, even if wealthy and influential. "Christ-loving" is a typical royal / imperial epithet; "pious" is mostly used in reference to inferior titles (the tsar's epithet is usually "faithful"), but is also commonly used for rulers. The expression "during the days of", with reference to persons in power, also testifies to a kind of ruler's position. We find the same formula in the colophon of the manuscript CHAI 1521. In the latter, the city is qualified in a manner common to the Byzantine tradition with regard to capitals: вZ вгохраниме м'всте Кратове. The use of the term "God-saved" is most significant, as it relates to the complex Powerand-City and to the heritage of Constantinople. It is also directly related to the veneration of Our Lady as protectress of the city; this was an essential part of the imperial ideology - to assert that the universal Empire and its capital is under the protection of God and the Mother of God. Undoubtedly, there was an obvious political element in the veneration of the neomartyrs, which could be related to knez Dimiter of Kratovo. In the colophon of CHAI 1562, he is mentioned as "knez", which places him in the category of local nobles and representatives of certain Christian communities in Western Bulgaria and Serbia - the term approximates to "major". He is mentioned together with the ecclesiastical head: kyr Macarius of the Archbishopric of the Serbian autocephalous Church in Peć, restored in 1557. Two years later, in 1564, knez Dimiter was "iconom of the Great Church of Iustiniana Prima" (i. e., of the Archbishopric of Ochrid). Some scholars believe that Kratovo was included in its diocese [17, pp. 18, 217]. In this context, the presence of knez Dimiter of Kratovo is a substitute for the missing Orthodox secular power in the literary works under research. For obvious reasons, we find mentioned only the Ottoman secular power in the person of the local eparch (the city governor) and the judge (the Ottoman kadi), who were not described pejoratively. The real persecutor of the martyrs was the Muslim rabble, not the official Ottoman power.

Thus, the only support the martyr obtains is from the Church, which represents the Christian people and is therefore a holder of power. This power should be conceived of in the perspective of the New Testament. It is the community of the faithful people and their spiritual leaders, representing the Church as Body of Jesus Christ. The martyr has a spiritual father - the local priest, and Saint Nicholas the Younger has a disciple - perhaps Matthew the Grammarian himself. They are not only eyewitnesses but actual participants in the events.

The manuscript CHAI 1521 is centered on calendar principles (of a synaxarium type) and 
encloses some texts related to the feasts in the month of May that follow the calendar day of Saint Nicholas the Younger (May 17). That is why the Vita and the Service for Saint George the Younger were not included in the codex. Otherwise, they would have been, Saint George being well known and venerated in his town of birth. This is one more reason to conclude that priest Lazar from Kratovo, who copied the manuscript, used an already prepared text matrix and did not compile the contents of the codex. CHAI 1521 has a very special content that aims to integrate the new commemoration of local saints, whose veneration appeared in a different socio-cultural context characterized by strong religious confrontation. In this respect, we have to pay attention to the spiritual relations between Sofia and Kratovo, which were long under the jurisdiction of the Archbishopric of Ochrid. During the first half of the $16^{\text {th }}$ century, this archbishopric, with its 33 local eparchies, reached its largest territorial spread. Obviously, the restoration of the Serbian Patriarchy in Peć in 1557 cut some eparchies away from Ochrid. Here, we shall limit ourselves to the observation that the neighboring regions of Sofia and Kratovo were under the influence of both ecclesiastical centers. We should also note the Serbian influence in Macedonia and Sofia during the late Middle Ages. Thus, we believe we have reason to study both centers - Sofia and Kratovo together in the same, or similar, religious, political and cultural context, a substantial element of which was the veneration of the neomartyrs and the literary production related to it.

During the $16^{\text {th }}$ century, the striving for integrity and continuity was a characteristic feature of the policy of the Church authorities under Ottoman rule. Neomartyrdom was obviously a factor of consolidation. We already mentioned the Serbian influence in Sofia and Kratovo, but these cities were also strongly linked to Ochrid. We should note the dedication of metropolitan cathedral churches to Saint Sophia the Wisdom of God in Service [4, pp. 570-575] and in Ochrid (pretending to be Iustiniana Prima). Such a dedication was relatively rare and demonstrated a significant political and religious reference, as it occurred only in capitals or in very important cities. Thus, we find churches dedicated to Saint Sophia in Constantinople, Thessalonica, and Kiev. This represents a dedication to Our Lord Jesus Christ and refers to the Constantinopolitan model.

4. The literary texts of the cult and memory. The spiritual milieu in Kratovo, in the mid- $16^{\text {th }}$ century was such as stimulated the veneration of the Sofia neomartyrs. The veneration in question naturally required certain literary texts to be used for the commemorative cult. The Eulogy was a panegyric speech that aimed at an educative impact; it became the "best operative instrument" $[5$, pp. 5-23] in the relation between the priest and the people. Quite possibly, the common Eulogy was intended to serve as a sermon and be read publicly in the church on the feast day of Saint Nicholas in May. It should specially be noted that the manuscript CHAI 1521 has numerous marginal notes containing calculations of the number of years elapsed from the death of Saint Nicholas to the date of the writing: this was a significant way of keeping alive the memory of the martyr in the city of his martyrdom. The local Christian community did its best to sanctify its city under Muslim rule and to create a specific sacral space centered on fidelity to Orthodoxy and the maintenance of the Church, viewed as a unity of the people and the clergy, who all suffered together during the martyrdom of "the defender of the faith in our times", as Saint Nicholas was called.

The Vita of Saint Nicholas relates how the Muslims of Sofia tried hard to prevent the emergence of a new local Christian cult and to frustrate the preservation of the saint's memory. They burned Saint Nicholas's body in order to make him disappear. The most respected objects of veneration after the death of the physical person, namely the relics, had to vanish completely. The Muslims had previously proceeded in the same way with George the Younger. Saint Nicholas's Vita, in keeping with the historical situation, presented a different perspective on holiness. The model of holiness did not comprise the relics at all. Moreover, the Lives of Saint Georges the Younger and of Saint Nicholas made it clear that the deliberate burning of the body by the Muslims, after a series of tortures, represented the crown of martyrdom. The words of the torturers according to the Life of Saint George are telling: "Do not believe you will obtain any part of his body! We shall burn him entirely, and we shall scatter his ashes in the air" [13, p. 306]. Thus, the paradigm of holiness was fulfilled in a 
stable city-descriptive program, in which Sofia played the basic role. Let us trace some of the most important elements of this program.

Matthew the Grammarian consciously strove to integrate his new work into the traditions of martyrology, though it was written in a new socio-cultural environment, under conditions of intense religious confrontation; he had broken free of the mandatory norms entailed by specific textual categories. He chose the model of projecting saintliness by taking it from history and situating it in the contemporaneous $16^{\text {th }}$ century, and by shifting it from the outward geographic location to an internal sphere of spiritual content. According to the hagiographic schema, the birthplace of the future martyr is, by definition, holy and pious. Sofia is the place raised to a higher rank in Matthew's work, and compared by him to the "Promised Land", richly watered, like God's Paradise. In this schema, the city is an organizing dominant of the holy space. The hagiographic hero walks the road to the place of his earthly death in order to continue his eternal life in heaven. The description is distinguished by its double structure: on the one hand, the use of images and symbols taken from the Biblical semantic code, and on the other, some kind of historical authenticity. In the beginning of his description, the author places the land of Sredets against a broad historical and geographic background not only by referring to макє, , омїи (in Macedonia), as this large area of the Balkans was called in the literature of that period, but

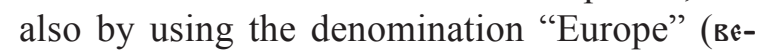
хицєи європіи), the continent - the city is located at the intersection of the ancient Roman routes connecting Central Europe to Constantinople and the Danube to Thessalonica. Sofia was reputed for its natural beauties, mountains, cold springs and healing thermal waters. Its external beauty was so undeniable that it outrivaled many other places in Arabia, Palestine, the Roman province Illyricum, Egypt, and the Italian lands. But once again, the geographic landmarks are merely external projections of the internal continuum of the Orthodox holiness of past times. Thus, being aware how much Sofia excels "not in breadth and great buildings" but in piety, the author goes on to present some chronological references to early Christian history and those of its greatest defenders who had left traces in what was once called Sardikia (from Sardica), as well as other major examples taken from the Christian history of the city.

Respecting the chronological succession, Matthew the Grammarian offered readers a sacralized history of Sofia, making references to historical figures or realia that embodied the idea of Christian sanctity. This was a sure way to preserve the historical memory of the sacred place and to create a particular type of expectation about the future of Christianity in the Balkans. The first reference is to the Church Council of Sardica in 343, which confirmed the Nicaean Symbol of Faith and issued 20 rules of the Holy Ecumenical Christian Church. It was attended by distinguished Christian thinkers and ecclesiastical figures, including Saint Athanasius the Great, Bishop of Alexandria. The second reference, to past and present martyrdoms in Sofia, was also related to the city's sacred history. While Matthew the Grammarian, in presenting the legend of the early Christian martyr Saint Therapontus of Sardis (who suffered in Phrygia circa AD 250-260), connected him to $16^{\text {th }}$-century Sofia as the place of his martyrdom, the reminder of Sredets as a holy place for the hermit Saint John of Rila and for the exploits of St. George the New of Sofia and St. George the Youngest of Sofia, was based on an authentic historical localization. The basic idea was to foster the vision of how ever-burning holiness had been present here since early Christian times and up to the time of the $16^{\text {th }}$-century Sofia martyrs. The third reference was to the holy environment of the city: the numerous churches in Sofia and the network of monasteries around it, which merited the name of the Little Holy Mountain of Sofia. Following the Athonite model, the monastic agglomeration around Sofia reproduced a holy space as an isle of Orthodoxy within an alien religious environment. In discussing this passage from the Vita of Saint Nicholas the Younger, researchers usually argue that the author was employing hyperbole and idealization, mostly because Matthew the Grammarian spoke about "the daily erection and affirmation of holy churches in the city and all around". However, the Vita contains something more important and, to some extent, symbolic: the allusion to the Great Holy Apostolic Church of God shining amidst the city. Was the compiler referring to a concrete church? According to his description, the church in question sheltered 
the wonder-working relics of the Serbian king Stephen Uroš II Milutin; this fact was known to Silouan, the metropolitan of Sardica, who had transferred the relics from Trepča to Sofia in 1459. The same church also contained "the holy relics of the above-mentioned martyrs". It was called the "dressed bride of Christ" and a breeder with "the milk of Spirit"; it beatified by means of the Divine light of the righteous clergy - bishops, priests, deacons, lectors, domestics - and by uninterrupted liturgy. On the one hand, the Great Lampadarius might have had in mind the church of Saint Sophia, to which he was devoted. As we stressed above, the original Vitae of the Sofia martyrs George the Younger and Nicholas the Younger contained references to actual loci in the city's topography. Two churches are mentioned in the Vita of Saint George the Younger of Sofia: Saint Sofia and Saint Marina; indicated in the Vita of Saint Nicholas the Younger of Sofia is the church of the Ascension of Our Lord.

However, we may ask ourselves whether the author has not presented a general, symbolic depiction of the Ecclesia, the Church of Christ, with its most important characteristics indicated in the Symbol of the Faith and Orthodox ecclesiology. Among these are the Church as a spiritual pillow of the city and its Orthodox community, with the help of which the spatial continuum of Sofia's Orthodox sanctity has once again regained its grounds. If this later bipolar image-symbol seems plausible, we may conclude that the design of sanctity in the Vita of Saint Nicholas the Younger echoes in a specific way the established Byzantine Orthodox concept of the Church-City, as depicted in iconography [28; 19;24, pp. 39-41]. This image would be particularly significant for a city whose name is derived from the concept of Sophia, the Great Wisdom of God. Our assumption would not seem illogical, taking into account that the passage in question relies on three quotations from the Psalter and two from the Canticle of Canticles, reproduced literally or paraphrased. All these quotations praise "the courts of God, the abode of God, the Holy Church of God" (Ps 44:15, Song 4:1, 7:7, 2:5, Ps. 15:3, Ps. 83:1-2).

Holiness as a basic concept of Christian thought was also embodied in other Biblical topoi. In Matthew the Grammarian's work, the Divine Grace shed upon the city of Sofia is timeless and continuous, as well as reproduced here and now, thanks to the "flourishing piety of the city". The second basic concept mentioned is Upper Jerusalem - not in the description of the city, but as a final stop on the road of the hagiographic hero. Although this topos is formally missing, replaced with the medieval cliché expression цвсарьство, царьство певесьною, the allusion to the celestial home is present in all literary works from Sofia. In the Vita of St. George of Sofia, we should compare the especially important quotation from the Gospel of Matthew (5:14-15):

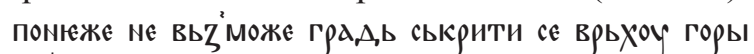

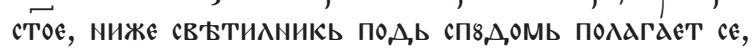

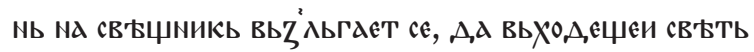
ви, А'тть [2, p. 236]. In the Vita of Saint Nicholas the Younger, the Orthodox ideologeme relevant to sanctity relies on the presentation of the martyr's city as a small model of God's kingdom, of a God-chosen place and God's home; there by the author confirms the Divine predestination of the hero, who, led by Divine providence and a guardian angel, came from elsewhere to absorb Sofia's holiness and, through his suffering, to impart additional sanctity to the city. Matthew the Grammarian writes about an Ottoman city that was Nicholas's birthplace and a city of his martyrdom, but he did not try to establish a similarity by using the "ruler" paradigm related to power. In this sense, we believe we should give him full credit for his original descriptive program regarding the city, a program that combines three sources: the Bible, history and legend. The verbal description of Sofia in the Vita by Matthew the Grammarian is one of the most recognizable creative elements in this work and an original contribution to hierotopy in the Balkans from the period of "Byzance après Byzance".

The concrete geographic descriptions and the data about the natural resources of Sofia, the abundant historical information, were just a starting point for shaping the sacralized image of the city as a spiritual space. Hence, in the Vita of Saint Nicholas, the epithets range from designations of basic qualities to stable clichés, inherited from the descriptive tradition regarding cities in Byzantine and Slavonic literature. The model of praising had changed in $16^{\text {th }}$ century hagiography with regard to the institution of ruler, but it preserved the connection with tradition with regard to fidelity to Orthodoxy. The hymnographic material from the Sofia literary school uses 
two-part adjectival modifiers for the city, verbs, and specific stylistic-rhetorical formulas in the praises (encomiums) of Sofia, shaped through an anaphora of the imperative "Rejoice, city", or the so-called heretisms. This was a favorite device of Old Bulgarian writers and became a major rhetorical convention in a number of works. It is worth noting that verbal formulas of that kind were used both in hymnographic works and in the anonymous Eulogy, an example of oratory prose. Being only one of many similarities, this feature demonstrates the unity of artistic principles and that Matthew was following Old Bulgarian models.

An important and typical feature of the Vitae of Sofia neomartyrs are the literary patterns borrowed from the evangelical narrative about the Passion of Our Lord Jesus Christ. In the Vitae, we find certain narratives that repeat the Gospel story of the Passion: the image of the pious Christian who shines in youth, goodness and honor. He is a relatively wealthy man who enjoys the respect of his community. He is peace-loving and does not provoke the aggression of the Muslims except by his excellent personal qualities. It was not the Ottoman authorities who incited and brought about the tragic events, but the fanatical Muslim rabblethe same people who had tried to attract the young Christian would, in failing to do so, try to destroy him. The Ottoman authorities play the role of the Romans in the Gospel. The local governor-judge is presented in the role of Pontius Pilatus: he is aware that the martyr is innocent but finally cedes to the rabble. The Christian community can do no more than give some spiritual and moral support to the martyr. The people were eyewitnesses of his passion and afterwards kept and cared for his memory.

We should pay special attention to the question of relics. Due to the special concern of the Muslims, there are practically no, or very few, relics of the Sofia neomartyrs. In this respect there is, again, a similarity to the Lord's and the Holy Virgin's relics: due to the Resurrection and Assumption in body, we have only objects from Jesus and Mary, and no corporal remains like those of other saints. Faithful Christians only have for their worship the Holy Places where the Lord and the Mother of God lived, and certain contact relics: the Holy Cross, the Mandilion, the instruments of the Passion, the Holy Veil of Our Lady, and other such.
Can we look for a similarity to the neomartyrs in this respect? To some extent, we can: we have almost no bodily relics, holy memory and a holy urban space created through a verbal image. This space is sanctified by the Presence of God that is attained by affiliation to His image through the saintly man's imitation of Christ. It is important to note that the sacralization of space is a result of special and purposeful efforts. On one hand, there is the preparation of the future martyr for his martyrdom; he must thereby consolidate the Christian community. On the other hand, there is the creation of the verbal image of the city in the framework of the new cult's literary works that point to a definite religious and political goal.

5. Conclusion. We have tried to argue that the aims of the veneration of Sofia neomartyrs were religious and political, and that these aims were attained through the exaltation of the Christian faith and the creation and maintaining of a historical memory. The direction of the intended results, however, was not anti-Ottoman but anti-Islamic; the veneration aimed to consolidate the Orthodox Christian congregation. It is to the people of Orthodox confession, not to the "national" (in this period mostly "ethnical") community, that the veneration of the neomartyrs was addressed. The strengthening of the congregation could be achieved excellently through the martyr's bearing witness (having in mind that "martyros" means "witness" in Greek); the martyr adds holiness to the place and sacralizes the city space. The witness is not only the creator of sacredness, he is also a keeper of the memory of the past. The martyr is a champion because he / she vanquishes the foes of God through his / her martyrdom. As a champion, he is a reminder of the glorious past; as a victor, he is a defensor fidei in the present. This is a clear confirmation of God's power under different historical circumstances. Thus, the same result is obtained as by M. TsibranskaKostova the translatio of holy models: that of (Upper) Jerusalem and of Constantinople for the city, and of (Lower) Mount Athos for the (holy) place. They are both directed at the restoration, but only spiritual, of the Christian Empire through the Body of the Church. This explains the absence of any overt opposition against Ottoman power. Therefore, we find here a conception of Byzance après Byzance of the 
same type as we find in Constantinople after the fall of the Empire, when the Ecumenical Church adopted part of the Empire's heritage.

\section{NOTES}

${ }^{1}$ The financial support from the Bulgarian Academy of Sciences under Bilateral grant agreement between BAS and the Romanian Academy (The Project "Religious rhetoric of power in the Byzantine and Balkan Middle Ages Institut des études sud-est européennes, Académie roumaine") is gratefully acknowledged.

The scientific editing of the article is realized by Yury Vin.

${ }^{2}$ It is well known that "Житије Георгија Кратовца" ("Zhitije Georija Kratovtsa") ["The Live of George Kratovtsa"], published by D.D. Bogdanović in particular, is attributed as “Житие Георгия Нового" (“Zhitie Georija Novogo") [“The Live of George Young"].

${ }^{3}$ The abbreviation "СНАІ" (“ЦИАИ”): Църковно-исторически и архивен институт. Св. Синод на Българската Православна църква; Българска Патриаршия. София (Ts'rkovno-istoricheski i arkhiven institut. Sv. Sinod na Bulgarsata Pravoslavna ts'rkva; Bulgarska Patriarshiya. Sofia).

\section{BIBLIOGRAPHY}

1. Ангелов, Б. Ст. Из старата българска, руска и сръбска литература. Кн. 3 / Б. Ангелов. - София : БАН, 1978. - 281 с.

2. Богдановић, Д. Д. Житије Георгија Кратовца / Д. Д. Богдановић // Зборник историје књижевности. Одељење језика и књижевности. - 1976. Књ. 10. - С. 203-267.

3. Буюклиева, А. Г. Житие на Николай Нови Софийски от Матей Граматик в контекста на житийната традиция / А. Г. Буюклиева. - София : Врьмл, 2008. - 312 с.

4. Градева, Р. С. Софийската катедрална църква XV - началото на XIX век / Р. С. Градева // Балканите. Модернизация, идентичности, идеи : сборник в чест на проф. Надя Данова / отг. ред. Ю. Т. Константинова. - София : Ин-т за балканистика, 2011. - С. 564-583.

5. Грашева, Л. Б. Поглед върху старобългарската ораторска проза / Л. Б. Грашева // Стара българска литература. В 7 т. Т. 2. Ораторска проза / ред. Б. Ст. Ангелов [и др.]. - София : Бълг. писател, 1982. - С. 5-29.

6. Калиганов, И.И.Георгий Новый увосточных слвян / И. И. Калиганов. - М. : Индрик, 2000. - 798 с.

7. Кожухаров, Ст. Е. Тах Андрей - един незабелязан химнописец от XVI в. / Ст. Е. Кожухаров
// Старобългарска литература. - 1985. - Кн. 18. C. $150-160$.

8. Кожухаров, Ст. Е. Химнографска интерпретация на софийските мъченичества от XVI век. Инок Андрей. Служба за Николай Софийски. / Ст. Е. Кожухаров // Проблеми на старобългарската поезия. Т. 1. - София : Боян Пенев, 2004. С. 259-278.

9. Михайлов (Апостолов), А. Един неизвестен софийски мъченик / А. Михайлов // Старобългарска литература. - 1971. - Кн. 1. - С. 403-411.

10. Николов, А. Н. П.А. Сирку в България (1878-1879) / А. Н. Николов, Л. А. Герд. - София : Боян Пенев, 2012. - 432 с. - (Studia mediaevalia Slavica et Byzantina ; т. 3).

11. Райкова, М. А. Похвална беседа за софийските мъченици / М. А. Райкова // Palaeobulgarica. 2010. - № 1. - С. 61-94.

12. Снегаров, И. И. Поглед към изворите за св. Никола Софийски / И. И. Снегаров // Годишник на Софийския университет. Богословски факултет. - 1932. - Т. 9. - С. 1-74.

13. Стара българска литература. В 7 т. Т. 4. Житиеписни творби / ред. Б. Ст. Ангелов [и др.]. София : Бълг. писател, 1986. - 688 с.

14. Сырку, П. А. Очерки из истории литературных сношений болгар и сербов в XIV-XVII веках. Житие св. Николая Новаго Софийского по единственной рукописи XVI в. / П. А. Сырку. - СПб. : Тип. Императ. Акад. наук, 1901. - CCCXI, VI, 176 с. (Сборник Отделения русского языка и словесности Императорской Академии наук ; т. 71, № 2).

15. Темелски, Хр. И. Храмът св. Николай Нови Софийски / Хр. И. Темелски. - София : Синева, 2000. -214 c.

16. Христова, Б. В. Български ръкописи от ХІ до XVIII век, запазени в България. Своден каталог. Т. 1 / Б. В. Христова, Д. М. Караджова, А. К. Икономова; под ред. И. С. Дуйчев, Б. Н. Райков. - София : Народна библиотека «Кирил и Методий», 1982. - 366 с.

17. Христова, Б. В. Бележки на български книжовници X-XVIII в. Т. 2. XVI-XVIII век / Б. В. Христова, Д. М. Караджова, Е. Г. Узунова ; науч. ред. Б. Н. Райков, Д. Н. Петканова. - София : Народна библиотека «Кирил и Методий», 2004. - 387 с.

18. Цибранска-Костова, М. П. Към езиковата практика на Софийската книжовна школа от XVI век: преводните синаксарни жития в ръкопис ЦИАИ 1521 / М. П. Цибранска-Костова // 145 години Българско книжовно дружество: езиковедски изследования. Приложение към сп. «Български език», 2014 / ред. И. Д. Златанов. - София : Емас, 2014. - С. 200-213.

19. Biliarsky, Iv. A. La demeure et la corne de l'Empire / Iv. A. Biliarsky // Orientalia Christiana Periodica. - 2003. - Vol. 69, Fasc. I. - P. 179-197. 
20. Biliarsky, Iv. A. La translation des reliques à la capitale du second empire bulgare et les idées du pouvoir / Iv. A. Biliarsky // Liturgia e agiografia tra Roma e Costantinopoli. Atti del 1 e 2 Seminario di Studio, Roma-Grottaferrata, 2000-2001 / a cura di K. St. Stantchev, St. Parenti. - Grottaferrata : Congregazione Monaci Basiliani, 2007. - P. 329-338.

21. Biliarsky, Iv. A. Le dernier voyage de saint Jean de Rila. La translation des reliques dans le contexte du début de la domination ottoman / Iv. A. Biliarsky // Les reliques en action. Variations juridiques sur la force agissante des choses sacrés / Dir. X. Perrot. - Limoges : Pr. univers. de Limoges, 2019. - P. 147-163.

22. Biliarsky, Iv. A. Imagines Virginis et la rhétorique du pouvoir dans l'œuvre littéraire du patriarche Euthyme de Tarnovo et de son cercle / Iv. A. Biliarsky // The Religious Rhetoric of Power in Byzantium and South-Eastern Europe. Proceedings of the Session held at the $12^{\text {th }}$ International Congress of South-Eastern European Studies (Bucharest, 2-6 September 2019) / ed. by Iv. A. Biliarsky, M. Mitrea, A. C. Timotin. - Brăila : Muzeul Brăilei “Carol I” : Ed. Istros, 2021. - P. 127-147.

23. Boeck, E. N. Imagining the Byzantine Past. The Perception of History in the Illustrated Manuscripts of Skylitzes / E. N. Boeck. - Cambridge : Cambr. Univ. Pr., 2015. - XVIII (XXII), 314 p., 16 pl.

24. Erdeljan, J. Chosen Places. Constructing New Jerusalems in Slavia Orthodoxa / J. Erdeljan. - Leiden ; Boston : Brill, 2017. - XII, 264 p.

25. Guran, P. Invention et translation des reliques un cérémonial monarchique? / P. Guran // Revue des études sud-est européennes. - 1998. - Vol. 36, Pts. 1-4.P. 195-229.

26. Iorga, N. Byzance après Byzance. Continuation de "L'Histoire de la vie byzantine" / N. Iorga. Bucarest : Assoc. intern. d'Études du Sud-Est Europeen. Com. nat. roumain, 1935. - 312 p., 14 pl.

27. L'Empereur hagiographe. Culte des saints et monarchie byzantine et post-byzantine / ed. par B. Flusin ; publ. de P. Guran. - Bucureşti : New Europe College, 2001. - 376 p.

28. Lidov, A. M. Heavenly Jerusalem : The Byzantine Approach / A. M. Lidov // Jewish Art. - 1998. - Vol. 23-24. - P. 340-353.

29. Vaporis, M. N. Witnesses for Christ. Orthodox Christian Neomartyrs of the Ottoman period 1437-1860 / M. N. Vaporis. - Crestwood, N. Y. : St Vladimir's Seminary Pr., 2000. - XIV, 377 p.

30. Zachariadou, E. A. The Neomartyr's Message

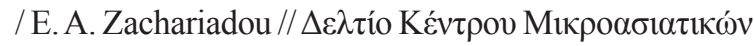

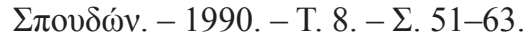

31. Zachariadou, E.A. Religious Dialogue between Byzantines and Turks during the Ottoman Expansion / E. A. Zachariadou // Religionsgespräche im Mittelalter. Vorträge, gehalten anläßlich des 25. Wolfenbütteler Symposions vom 11.-15. Juni 1989 in der Herzog-Au-
gust-Bibliothek / hrsg. von B. Lewis, F. Niewöhner. Wiesbaden : Harrassowitz, 1992. - S. 289-304.

32. Zachariadou, E. A. The Neomartyr's Message // Studies in Pre-Ottoman Turkey and the Ottoman / E. A. Zachariadou. - Burlington : Ashgate, 2007. P. 51-63. - (Variorum Collected Studies Series ; vol. 882).

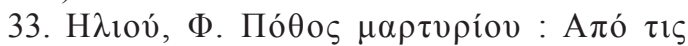

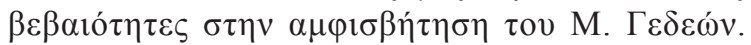
$\Sigma v \mu \beta$ о

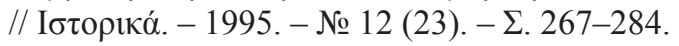

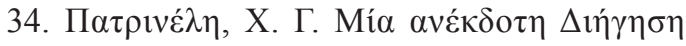

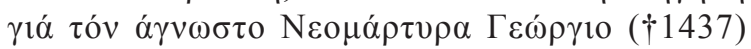

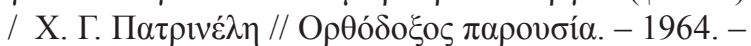

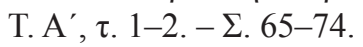

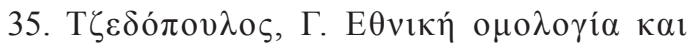

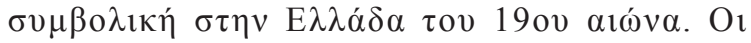

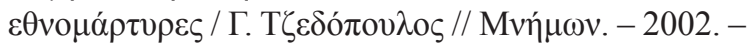
T. 24. $-\Sigma$. 107-143.

\section{REFERENCES}

1. Angelov B.St. Iz starata balgarska, ruska $i$ srabska literatura. Kn. 3 [From the Old Bulgarian, Russian and Serbian Literature. Vol. 3]. Sofia, BAN Publ., 1978. 281 p.

2. Bogdanović D. Zhitije Georgija Kratovtsa [The Live of George Kratovtsa]. Zbornik istorije knjizhevnosti. Odeljenje jezika i književnosti [Collection of Works on the History of Literature. Language and Literature Course], 1976, vol. 10, pp. 203-267.

3. Buyuklieva A.G. Zhitie na Nikolay Novi Sofiysky ot Matey Gramatik in konteksta na zhitiynaya traditsiya [The Life of Nicolay Sofiysky by Mattheus Gramatic in Context of Hagiographical Tradition]. Sofia, Vreme Publ., 2008. 312 p.

4. Gradeva R.S. Sofiyskata katedralna tsarkva XV - nachaloto na XIX vek [The Sofia Cathedral of the $15^{\text {th }}-$ Early $19^{\text {th }}$ C. $]$. Konstantinov Yu.T., ed. Balkanite. Modernizatsia, Identichnosti, Idei. Sbornik v chest na prof. Nadya Danova [The Balkan. The Modernization, Identities, Ideas. The Collection in Honor of Prof. Nadya Danova]. Sofia, In-t za balkanistika, 2011, pp. 564-583.

5. Grasheva L. B. Pogled varkhu starobalgarskata oratorska proza [The View of Old Bulgarian Orator Prose]. Angelov B.St. et al., eds. Stara balgarska literature. $V 7$ t. T. 2. Oratorska proza [The Old Bulgarian Literature. In 7 Vols. Vol. 2. Orator Prose]. Sofia, Balg. pisatel Publ., 1982, pp. 5-29.

6. Kaliganov I.I. Georgiy Novyy u vostochnykh slavyan [George Young of the East Slavonians]. Moscow, INDRIK Publ., 2000. 798 p.

7. Kozhukharov St.E. Tah Andrey - edin nezabelyazan himnopisets ot XVI v. [The Humble Monk Andrej - An Unnoticed Hymnograph of the 
$16^{\text {th }}$ c.]. Starobalgarska Literatura [Old Bulgarian Literature], 1985, vol. 18, pp. 150-160.

8. Kozhukharov St.E. Himnografska interpretatsiya na sofiyskite machenichestva ot XVI vek. Inok Andrey. Sluzhba za Nikolay Sofiyski [The Hymnographic Interpretation of Sofia Martyrdoms of the $16^{\text {th }}$ c.]. Problemi na starobulgarskata poeziya. T. 1 [The Problems on the Old Bulgarian Poetry. Vol. 1]. Sofia, Boyan Penev Publ., 2004, pp. 259-278.

9. Mikhaylov (Apostolov) A. Edin neizvesten sofiyski machenik [An Unknown Sofia Martyr]. Starobalgarska literatura [Old Bulgarian Literature], 1971, vol. 1, pp. 403-411.

10. Nikolov A.N., Gerd L.A. P.A. Sirku v Balgariya (1878-1879) [P.A. Sirku in Balgaria (1878-1879)]. Sofia, Boyan Penev Publ., 2012. 432 p. (Studia mediaevalia Slavica et Byzantina; vol. 3).

11. Raykova M.A. Pohvalna beseda za sofiyskite machenitsi [The Laudatory Conversation on the Sofia Martyrs]. Palaeobulgarica, 2010, no. 1, pp. 61-94.

12. Snegarov I.I. Pogled kam izvorite za sv. Nikola Sofiyski [The View of Sources on St. Nikola of Sofia]. Godishnik na Sofiyskiya universitet. Bogoslovski fakultet [The Year-Book of Sofia University. The Theological Faculty], 1932, vol. 9, pp. 1-74.

13. Angelov B.St. et al., eds. Stara balgarska literatura. $V 7$ t. T. 4. Zhitiepisni tvorbi [The Old Bulgarian Literature. In 7 Vols. Vol. 4. Hagiographical Works]. Sofia, Balg. pisatel Publ., 1986. 688 p.

14. Syrku P.A. Ocherki iz istorii literaturnykh snosheniy bolgar i serbov $v$ XIV-XVII vekakh. Zhitie sv. Nikolaya Novago Sofiyskogo po edinstvennoy rukopisi XVI v. [The Essays on History Literary Relations of Bulgarians and Serbs in the $14^{\text {th }}-17^{\text {th }} \mathrm{cc}$. The Life of St. Nikolay Young of Sofia by the Single Manuscript of the $16^{\text {th }}$ c.]. Saint Petersburg, Tip. Imp. Akad. nauk Publ., 1901. CCCXI, VI, 176 p. (Sbornik Otdeleniya russkogo yazyka i slovesnosti Imperatorskoy Akademii nauk; t. 71, № 2 [The Collection of Department of Russian Language and Literature of the Imperial Academy of Sciences; vol. 71, no. 2]).

15. Temelsky Chr.I. Hramat sv. Nikolay Novi Sofiyski [The Church of St. Nikolay Young of Sofia]. Sofia, Sineva Publ., 2000. 214 p.

16. Khristova B.V., Karadzhova D.M., Ikonomova A.K. Balgarski rakopisi ot XI do XVIII vek, zapazeni v Balgaria. Svoden katalog. T. 1 [The Bulgarian Manuscripts of the $11^{\text {th }}-18^{\text {th }}$ C., Kept in Bulgaria. The Combined Catalogue. Vol. 1]. Sofia, Narodna biblioteka "Kiril i Metodiy" Publ., 1982. 366 p.

17. Khristova B.V., Karadzhova D.M., Uzunova E.G. Belezhki na balgaraski knizhovnitsi $X-X V I I I$ v. T. 2. XVI-XVIII v. [The Notes to Bulgarian Writers of the $11^{\text {th }}-18^{\text {th }} \mathrm{cc}$. Vol. 2. The $16^{\text {th }}-18^{\text {th }} \mathrm{cc}$.].
Sofia, Narodna biblioteka "Kiril i Metodiy" Publ., 2004. 387 p.

18. Tsibranska-Kostova M.P. Kam ezikovata praktika na sofiyskata knizhovna shkola ot XVI vek: prevodnite sinaksarni zhitiya $\mathrm{v}$ rakopis TsIAI 1521 [To the Language Practica of the Sofia Literary School of the $16^{\text {th }}$ C.: The Translated Synaxarium Lifes in Manuscriptum CHAI 1521]. Zlatanov I.D., ed. 145 godini Balgarsko knizhovni druzhestvo: ezykovedski izsledovaniya. Prilozhenie kam spisaniya "Balgarski ezik", 2014 [145 Years of Bulgarian Literary Society: Linguistic Studies. Addition to Journal "Bulgarian Language", 2014]. Sofia, Emas Publ., 2014, pp. 200-213.

19. Biliarsky Iv.A. La demeure et la corne de l'Empire. Orientalia Christiana Periodica, 2003, vol. 69, fasc. I, pp. 179-197.

20. Biliarsky Iv.A. La translation des reliques à la capitale du second empire bulgare et les idées du pouvoir. Stantchev K.St., Parenti St., ed. Liturgia e agiografia tra Roma e Costantinopoli. Atti de I e II Seminario di Studio Roma-Grottaferrata, 2000-2001. Grottaferrata, Congregazione Monaci Basiliani, 2007, pp. 329-338.

21. Biliarsky Iv. Le dernier voyage de saint Jean de Rila. La translation des reliques dans le contexte du début de la domination ottoman. Perrot X., ed. Les reliques en action. Variations juridiques sur la force agissante des choses sacrés. Limoges, Pr. univers. de Limoges, 2019, pp. 147-163.

22. Biliarsky Iv. Imagines Virginis et la rhétorique du pouvoir dans l'œuvre littéraire du patriarche Euthyme de Tarnovo et de son cercle. Biliarsky Iv., Mitrea M., Timotin A. C., eds. The Religious Rhetoric of Power in Byzantium and South-Eastern Europe. Proceedings of the Session Held at the $12^{\text {th }}$ International Congress of South-Eastern European Studies (Bucharest, 2-6 September 2019). Brăila, Muzeul Brăilei "Carol I"; Ed. Istros, 2021, pp. 127-147.

23. Boeck E.N. Imagining the Byzantine Past. The Perception of History in the Illustrated Manuscripts of Skylitzes. Cambridge, Cambr. Univ. Pr., 2015. XVIII (XXII), 314 p., 16 pl.

24. Erdeljan J. Chosen Places. Constructing New Jerusalems in Slavia Orthodoxa. Leiden, Boston, Brill, 2017. XII, 264 p.

25. Guran P. Invention et translation des reliques un cérémonial monarchique? Revue des études sud-est européennes, 1998, vol. 36, pts. 1-4, pp. 195-229.

26. Iorga N. Byzance après Byzance. Continuation de "L'Histoire de la vie byzantine". Bucarest, Assoc. intern. d'Études du Sud-Est Europeen. Com. nat. roumain, 1935.312 p., 14 pl.

27. Flusin B., Guran P., eds. L'Empereur hagiographe. Culte des saints et monarchie byzantine et post-byzantine. Bucureşti, New Europe College, $2001.376 \mathrm{p}$. 
28. Lidov A. Heavenly Jerusalem: The Byzantine Approach. Jewish Art, 1998, vol. 23-24, pp. 341-353.

29. Vaporis M.N. Witnesses for Christ. Orthodox Christian Neomartyrs of the Ottoman Period 1437 1860. Crestwood, N.Y., St Vladimir's Seminary Pr., 2000. XIV, 377 p.

30. Zachariadou E.A. The Neomartyr's Message. Deltio Kentrou Mikroasiatikōn Spoudōn [Bulletin of the Center for Asia Minor Studies], 1990, vol. 8, pp. 51-63.

31. Zachariadou E.A. Religious Dialogue Between Byzantines and Turks During the Ottoman Expansion. Lewis B., Niewöhner F., ed. Religionsgespräche im Mittelalter. Vorträge, gehalten anläßlich des 25. Wolfenbütteler Symposions vom 11.-15. Juni 1989 in der Herzog-August-Bibliothek. Wiesbaden, Harrassowitz, 1992, S. 289-304.

32. Zachariadou E.A. The Neomartyr's Message. Zachariadou E.A. Studies in Pre-Ottoman Turkey and the Ottoman. Burlington, Ashgate, 2007, pp. 51-63. (Variorum Collected Studies Series; vol. 882).

33. Ēliou Ph. Pothos martyriou: apo tis bebaiotētes stēn amfisbētēsē tou M. Gedeōn. Symbolē stēn istoria tōn neomartyrōn [Desire for Martyrdom: from the Certainties to the Controversy of M. Gideon. Contribution to the History of the New Martyrs]. Istorika, 1995, no. 12 (23), pp. 267-284.

34. Patrinelē Ch.G. Mia anekdotē Diēgēsē gia ton agnosto Neomartyra Georgio ( $† 1437)$ [An Unpublished Narrative About the Unknown New Martyr George]. Orthodoksos parousia [The Orthodox Advent], 1964, vol. 1, no. 1-2, pp. 65-74.

35. Tzendopoulos G. Ethnikē omologia kai symbolikē stēn Ellada tou 19ou aiōna. Oi ethnomartyres [National Confession and Symbolism in the $19^{\text {th }}$ Century Greece. The National Martyrs]. Mnēmōn [Memories], 2002, vol. 24, pp. 107-143.

\section{Information About the Authors}

Ivan Alexandrov Biliarsky, DSc (Doctor Scientiarum Historiae), Professor, Institute of Historical Studies, Bulgarian Academy of Sciences, Boulevard Shipchenski prohod, 52, B1. 17, 1113 Sofia, Bulgaria, ivan.biliarsky@gmail.com, https://orcid.org/0000-0002-8084-8858

Mariyana Petrova Tsibranska-Kostova, DSc, Professor, Institute for Bulgarian Language, Bulgarian Academy of Sciences, Boulevard Schipchenski prohod, 52, B1. 17, 1113 Sofia, Bulgaria, tzibran@ibl.bas.bg, https://orcid.org/0000-0002-5699-7503

\section{Информация об авторах}

Иван Александров Билярски, DSc, профессор, Институт исторических исследований, Болгарская академия наук, бул. Шипченски проход, 52, бл. 17, 1113 г. София, Болгария, ivan.biliarsky@gmail.com, https://orcid.org/0000-0002-8084-8858

Марияна Петрова Цибранска-Костова, DSc, профессор, Институт болгарского языка, Болгарская академия наук, бул. Шипченски проход, 52, бл. 17, 1113 г. София, Болгария, tzibran@ibl.bas.bg, https://orcid.org/0000-0002-5699-7503 